\title{
THE IMPLEMENTATION OF THE EFFECTIVE STRATEGY FOR PRACTICING EXTEMPORANEOUS SPEECH STYLE IN PUBLIC SPEAKING
}

\author{
Novia Yulanda \\ English Education Department \\ Faculty of Tarbiyah and Teacher Training \\ State Islamic Institute of Bukittinggi
}

\section{Noviajuanda27@gmail.com}

\begin{abstract}
This research deals with public speaking class, especially in extemporaneous speech. The purpose of the research was to find out how was the effective strategy for practicing an impromptu speech in public speaking. The researcher applied a qualitative research approach. The technique of data collection was note-taking by collected data on books and journals. The data were analyzed using data reduction, data display, and drawing the conclusion. The results revealed that there are some effective strategies for practicing extemporaneous speech in public speaking. The introduction of the speech started from greeting the god, getting the attention and interest of the audience started by a familiar quote, telling a personal story to illustrate speech point, and revealing the topic to the audience. Strategies explaining the body of speech were to have a card note. It is used to write the point of the speech presents the main points and sub-points in the body of the speech. Establish eye contact with the audience into speaker opening words, vocal and visual gestures in perform, and make sure the speech has the desired impact on the audience, testimony quotes from expert statements to support the conversation. Then, strategies concluding the speech began the conclusion with a restatement of the speaker's message by using positive words to the audience, praise and thanks to the audience, closing with an entertaining sentence or anecdote, chant rhymes, and chant rhymes and short poems.
\end{abstract}

Keywords: Speech Delivery Style, Student Perform, Public Speaking

\section{INTRODUCTION}

Public speaking is one of the most practical classes will ever take, and often may be required to give presentations in other classes, and this course helps prepare you for that. Effective speaking skills give a tremendous 
advantage at work too. Overall, public speaking ability helps the speaker become a more active member of the community, allows the speaker to participate more fully in organizations you belong, and boosts the speaker's self confidence in both personal and professional contexts, It is no wonder that so many college graduates say public speaking was one of the most beneficial classes they took in school (Stephen, 2013).

Speaking skill is one of the important skills that must be mastered by the learners in learning English. Through speaking, speaker learns how to speak English easier because there are friends who can be their pairs to practice speaking English (Maxom, 2010). When speaker speaks, they interact and use the language to express their ideas and feelings. Speaking is not only remembering and memorizing the sentence, but speaking is spontaneous to show the speaker's idea orally.

Delivering your speech notes to remind you of the points you intend to cover. The notes should consist of key words or phrases, rather than complete sentences and paragraphs. This way, when you are in front of the audience, you will tell them what you know about the topic in your own words. Prepare your notes by writing or printing key terms and phrases on index cards or sheets of paper. Some instructors require students to use index cards because they are small and unobtrusive, do not rustle or flop over, and can be held in one hand, which allows the speaker to gesture more easily. Other teachers recommend sheets of paper because you can get more information on them and because it is easier to print out computer files on paper.

Speech is a series of speaking activities carried out in front of the general public or giving speeches in a statement of opinion, or giving an overview of something. Speeches can be made by several methods, introduction Importu is a method of speech which is done without prior preparation, Memoriter is a method of making speeches by memorizing the text script first, Manuscript is a method of giving a speech which is done by reading the text during the speech, Extemporaneous is a method of giving a speech, where the big concept of the speech will be conveyed during the speech. To become a good speaker and attract the audience, every speaker has a method in delivering a speech, one of which is the extemporaneous style is the most ideal style used by the speaker when delivering a speech.

Extemporaneous speaking is the art of giving speeches on the spot without notes or memorization relying only on the speaker's depth of knowledge and their ability to explain what they know in a coherent, engaging manner. As a category of forensics competition, extemporaneous speaking or "extemp" as it is commonly known is the manifestation of public speaking skills in their purest form without the support of notes or memorization, the speaker is on her own when she is in front of an 
audience, with only her memory, knowledge, and command of language to aid her.

Extemporaneous method requires you to know the content of your speech quite well. In fact, when you use this method properly, you become so familiar with the substance of your talk that you need only a few brief extemporaneous speech a carefully prepared and rehearsed speech that is presented from a brief set of notes. Your first speech provides a foundation for speeches you will give later. As you develop your skills of extemporaneous speaking, you will find yourself able to speak confidently and with strong eye contact in class and out.

Speech has a part were introduction of the speech, explaining the body of speech and concluding the speech. The research aimed at know about how was the effective strategic for practicing extemporaneous speech in public speaking so the researchers conducted an observation study, observing visits to the journal and book sites related to the study title to obtain data sources. The first observation was made in mid October 2020 through November 2020, with such an observation earned important points on the issue of public speaking.

Based on the data that researchers got in the journal, the problem in opening the speech is the speaker difficulty in determining the titles of an interesting speech, the speaker difficulty in starting the opening of the speech in order for audience to be interested in listening. The problem in delivering a speech is difficulty in developing the content of a speech, delivering the content of a speech by reading, not using the media or props for delivering a speech, grounding and being afraid to miss the part. The problem with closing a speech is the difficulty in drawing a conclusion because it does not understand the content of the speech (Husna, 2012).

Based on the data, the problem with opening a speech was a lack of confidence when it comes to the public; the problem with delivering a speech was a poor choice of wording which was unflattering (Edo, 2012). The problem with opening a speech was the difficulty of finding an interesting idea, the stage of the delivery of a speech was the lack of confidence to appear in public because of not understanding the content of the speech (Rizki, 2019).

Based on the explanation above, the reasons of the researcher are interested in this research, that the researcher wants to provide a better understanding about the effective strategy for practicing extemporaneously speech style in public speaking.

There are some studies related to this research. The researcher found some researches that are observe by some researcher as follow. First, the thesis conducted by Hoverove with the title "Element of Public Speaking Tools of building an Effective Speech". The study revealed that the effective 
speech is not only to create good speech which is clearly organized, supported by supporting material and completed by usage of lexical and syntactical items which will make the speech more vivid, but even more important part of the speech is way how the speech is said and the proper usage of nonverbal communication and vocal delivery (Hoverove, 2012).

Second, "L2 Speaking Strategies Employed By Indonesian EFL Tertiary Students Across Proficiency And Gender" written by Wahyuni. The research concluded that speaking proficiency and gender significantly affected the use of affective strategies only. The study also demonstrated that the students used strategies consciously, confidently, effortfully, or persistently because of the usefulness of the strategies or pleasure in using them (Wahyuni, 2013).

Third, "A Correlational Study between Students Speaking Ability and Students' Self Concept at the Tenth Grade Students of SMKN 1 Payakumbuh in Academic Year of 2010/2011" written by Astuti. The result showed that $\mathrm{r}=0,81$. It means that there was no correlation between students' speaking ability and students' self-concept at the ten grade students of SMKN 1 Payakumbuh in Academic Year of 2010/2011 (Astuti, 2011).

\section{METHOD}

Data collection techniques will be taken from the data source. The data source intended in this research is the goal from which data can be obtained. If the researcher uses documentation, then the documentation or notes are the source of data. While the contents are notes of research subjects or research variables (Suharsimi, 2006). The source of data used:

a. Primary Data

Primary data is data get from the first source in the form of a library that contains new scientific knowledge or new understanding of facts or ideas directly. Primary data sources are data sought by researchers and data obtained directly from research subject. And this primary data is also called first data (Saifuddin, 2009).

b. Secondary

While secondary data is source that cannot provide information directly to the data collector. Secondary data source is data obtained from other parties. Not directly obtained by research subject. In other words, secondary data is supporting data from primary data or firsthand data. Secondary from this research will take various source such as books, journal.

Technique of data analysis from this research uses content analysis. Qualitative studies are used to technique data analysis by content analysis with the conceptual zone. Initially the words are gathered into common reference elements so that is so simple for construct concept. The concept is 
hoped to adjustment the contents or messages of the work comprehensively (Saifuddin, 2009). The steps applied in analyzing data are:

1. Data Reduction

In the process of reducing and summarizing, the data will record and summarize by taking important things that reveal the theme of the problem. Then notes have been obtained in the field with the description, the result of the construction is arranged in the form of reflection. Reports that need to be reduced, summarized, sorted out the main things, focus on things that are important, looking for themes or patterns.

2. Display Data

Data display categorizes the unit of analysis based on the focus and aspect of the problem under research, or data that is stacked, thick reports by itself will be difficult to see the overall picture to draw agree with the conclusions.

\section{Drawing Conclusion}

The final step is to conclude the data that allows the validity of the result obtained from the research. From the beginning the researcher must try to find the meaning of the data collected. From the data obtained, the researcher tries to draw conclusions that are usually still vague, doubtful. But, with increasing data the conclusion will be clearer. So, conclusion must always be verified throughout the research.

\section{FINDINGS AND DICUSSION}

The extemporaneous method was a speech that is based on preparation, but the speaker presents his or her ideas freely by only using an outline or keywords. It is a carefully planned and well-prepared speech; extemporaneous speech style is an ideal method of speech because most speakers use extemporaneous speech style. Speakers need to practice so that the preparation, the extemporaneous speech style had a strategy for practice extemporaneous speech style in public speaking.

Based on the findings of this research, the research also aimed to present research questions that have been answered due to the result of this research. To answer the research question, the researcher conducted descriptive qualitative research to analyse the phenomena to found detailed information. The data source of this research was from books and journal.

According to the research question how was the effective strategy for practicing extemporaneous speech in public speaking, it can be concluded from the three elements of speech (introduction, explaining, and concluding). Based on the data from the book strategy to introduction the speech was to need an index card, get attention and interest the audience with a familiar quote, introduced controversial issues, don't talk too soon, establish a connection with the particular audience. The strategy to explain 
the body of speech was using an index card to write the keyword, eye contact speaker with an audience, (vocal, volume, pronunciation, body language), share ideas from the expert or practitioners, and show the statistic. The strategy to concluding the speech was to leave the final impression, summarize your speech and provide closure, signalling the end of your speech and motivating the audience to respond.

Based on the data from the journal strategy to introduction the speech was Start greeting to the god, get the audience's attention with a quotation so that the audience is interested in hearing the speech until the end. The strategy to explain the speech was to explain the content of the speech which is supported by facts, can be a story which is referred to as an illustration, analogy to compare two things to find similarities or differences, testimony quotes from expert statements to support the conversation, statistic, the numbers are used to show the comparison of cases in a certain type, repetition which functions to remember again with a different presentation.

So, the research result showed that the effective strategy for practicing the extemporaneous speech in public speaking in introduction of the speech started greeting to the god, get attention and interest of the audience start by a familiar quote, tell a personal story to illustrate speech point, and reveal the topic to the audience. Strategies explaining the body of speech was has a card note to write the point of the speech, presents the main points and subpoints in the body of the speech, establish eye contact with the audience into speaker opening words, vocal and visual gesture in perform, give chance to make sure the speech has the desired impact to the audience, testimony quotes from expert statements to support the conversation. Strategies the concluding of the speech began the conclusion with a restatement of the speaker's message by used positive words to the audience, words of praise and thanks to the audience, closing with an entertaining sentence or anecdote, chant rhymes, and short poems.

\section{CONCLUSION}

According to the finding are investigated by the researcher toward the research question, how was an effective strategy for practicing extemporaneous speech in public speaking. There are some effective strategies for practicing the extemporaneous speech in public speaking. The introduction of the speech started from greeting the god, getting the attention and interest of the audience started by a familiar quote, telling a personal story to illustrate speech point, and revealing the topic to the audience. Besides, to arrange the body of the speech can use a card note. Establish eye contact with the audience into speaker opening words, vocal and visual gestures in perform, and make sure the speech has the desired impact on the audience. Then, strategies concluding the speech began the 
Available online at https:/ /jurnal.iainponorogo.ac.id/index.php/eltall

conclusion with a restatement of the speaker's message by using positive words to the audience. The closing takes no more than 5 to 10 percent of the speech.

\section{REFERENCES}

Astuti, Sri Silvia. (2011). A Correlation Study Between Students Speaking Ability and Student Self Concept at the Tenth Grade Students of SMKN 1 Payakumbuh 2010/2011 Academic Year. (Unpublished Study).

Bailey, Jessica. (2013) Extemporaneous speaking. National Speech \& Debate Association.

Beebe, A Steven, Beebe J Susan.(2013) Publick speaking Handbook. Pearson Education, Inc

Bramantio, Edo. (2012) Peningkatan kemampuan berpidato dengan metode pemodelan pada siswa kelas xi SMA pancasila purworejo. Purworejo.

Carnegie, Dale.(1915) The art of public speaking. The home coresponden school.

Charli Hepy and Syafri Hayati, S.S, M.Pd. (2016). Furnishing English Students'proficiency For Being Public Speaker To Multilingual Society At Educational Major. IAIN Bukittinggi.

Coopman, Stephen J. Lull, James. (2010). Public Speaking The Evolving Art. Boston: Wadsworth Cengage Learning.

Creswell. John W. (2008). Educational Research: Planning, Conducting, and Evaluating Quantitative and Qualitative Research. New Jersey: Pearson.

Dewi, Ratna idha.(2013).Imformative speaking using the Extemporaneous speech method in a university public class.

El Moratji, Latifa.(2017). Effect of sustained impromptu speaking anad goal settingon public speaking competency development: Acase study of EFL college Student in maroc. Canadian Center of Science and Education

Gay, L.R and Airisian, Peter. (2000). Educational Research: Competencies for Analysis and Application. United Stated of America: Mc Millan Publishing Company.

Gay, L.R et.al. (2011). Educational Research: Competencies for Analysis and Applications. United Stated of America: Pearson Education.

J Stephanie \& Lull James.(2010). Public Speaking The Eloving Art. San Jose State Universtiy.

Lucas, Stephen E. (2009). The Art of Public Speaking. New York: The McGrawHill Companies, Inc.

Luoma, S. (2004). Assessing Speaking. Cambridge: Cambridge University Press.

Morreale, Sherwyn. (2010). The Competent Public Speaker. New York: Peter Lang Publishing. 
Vol. 2 No. 2, 2021

Available online at https:/ /jurnal.iainponorogo.ac.id/index.php/eltall

Lu'lu'ul Asiyah, Husna. (2012) Peningkatan keterampilan pidato persuasi dengan media barang produk siswa kelas xii ips ma wahid hasyim Yogyakarta. Universitas Negeri Yogyakarta.

Nesa, Rifka. (2015). An Analysis the Second Year Student's Strategies In Overcoming The Anxiety In Public Speaking Of English Department STKIP Abdi Pendidikan Payakumbuh 2014/2015 Academic Year. (Unpublished Study)

Nikitina, Arina. (2011). Successfull Public Speaking. Academic Transfer.com.

Mufanti, Restu Elok, Nimasari, Putri Rohfin dkk. (2017) Can I be a speaker. Nata karya.

O'hair, Dan. Rubbenstein, Hannah. Stewart,Rob. (2010). A Pocket Guide To Public Speaking. Boston, New York: Bedford/St.Martin's.

Putra, Anggayuh aditya budi utama.(2015). Speech strategy used by Steve job in the Lounching of iphone: Universitas Brawijaya

Sabay, Kenneth G.(2016).Oral communication in context. C\&E Publishing,Inc, :South triangle,Quezon city

Setyojati, Iman. Laksono, Sedyo dkk. (2019). Persuasive strategy in prabowo's politicalspeech at National agenda.

Sugiyono.(2013). Statistika Untuk Penelitian.Bandung: Alfabeta.

Syafitri, Widya. (2017). Improving students' speaking ability through simulation. IAIN: Bukittinggi.

Trussell, Christy, (2015). Extemporaneous speaking talking to the next level: Dripping spring High School. 